\title{
REVIEW
}

\section{Growth or Development?: \\ A Review of The Prebisch Report on Latin America ${ }^{1}$}

\author{
by Dudley Seers ${ }^{2}$
}

When it became known that Dr. Prebisch was writing this report, expectations ran high. Clearly if his many talents were ever needed anywhere, the time is now and the place Latin America, facing its most profound crises. What would Prebisch recommend, looking at the region with a fresh eye after six years based in Geneva?

Reviewing his report is not a task to be undertaken lightly。 This is, after all, the culminating statement of the author's career, the latest of a distinguished series which Raùl Prebisch has produced for Latin America and then for the world, first as Executive Secretary of ECLA and later as Secretary-General of UNCTAD - combining almost uniquely the roles of diplomat, administrator, theoretician and researcher。 He is the greatest living practitioner, a sort of Beveridge on the international scene, and he has done more to educate us on development problems than any other living man, except perhaps (and in rather different ways) Gunnar Myrdal.

For this very reason he has a number of enemies, and I - who am especially indebted to him - have no wish to provide them with ammunition. In any case this, his latest report, is not just the mixture as before. He devotes much more attention than before to unemployment and income inequalities. The same applies to policy on population and technical transfers (though with some ambivalence), and there is a new emphasis on the dangers of economic tariffs. Interesting, though brief, references are made to the Soviet model and to the economic damage that can be done by advertising and by military expenditure. The section on the political requirements for tackling social problems marks a

1 'Change and Development: Latin America's Great Task' (InterAmerican Development Bank, 1970). I benefitted from discussions in the Latin American group at IDS before writing this review, and from attending a seminar in Santiago on the report, organised by IDB, ILPES and SID, at which I put forward the main points in this peper。

2 Dudley Seers is the Director of The Institute of Development Studies. 
particularly welcome step forward for a report published by a mitinational agency.

But still it is time, perhaps past time, to raise certain questions about the basic model he continues to use, onto which all these new themes are grafted。 This model, which serves to crystallise his philosophy of development, is a familiar one to students of Dr. Prebisch's work, even though a different main objective is specified now - to cure unemployment.

Tnis requires, the report says, a high growth rate, 8 per cent for Latin America as a whole by 1980. This in turn implies rapidly growing import demands; the burden can be eased by regional integration, but nevertheless the ex ante foreign exchange 'gap' would require a rising inflow of financial resources from abroad. From another point of view, these are needed to supplement donestic savings. The report concludes that for this 'gap' to be filled, import substitution and export promotion would need to be acselerated, and the flow of resources to all $1 \mathrm{dc}^{\prime} \mathrm{s}$ would need to reach the UNCTAD-Pearson target of 1 per cent of the developed countries' gross product by 1975, and Latin America would have to $r$ tain its ( 15 per cent) share of these flows, and the terms of a.id would need to become much easier.

The first question is: what is the purpose of refurbishing gippery? Do regional projections justify such a heavy emphasis? The message to Latin Americans to accelerate growth (there is much talk of 'discipline') hardly needs such statistical support. They must be addressed to the United States (and its affiliates). But would any calculations on these assumptions provide useful armunition for even a sympathetic Washington politician, granted the U.S. political scene as it is today?

Is this really the right framework, anyway? The crucial question is whether the main emphasis should be on speeding up tie growth rate or on changing the growth process. The logic of the Prebisch doctrine (a logic I myself once accepted) is that fast economic growth based on protected industrialisation would induce the advance of other sectors of the economy and the relief of social problems, following the patterm of development in Wastern Europe and North America.

Actually, the rate of economic growth has in itself not been ursatisfactory, averaging 5.2 per cent for Latin America as a whole from 1950 to 1968. Import substitution has made a big

Actually someone who believes, as Dr. Prebisch does, that the income distribution is morally wrong, cannot expect real national income comparisons, using the prices derived from this distribution as implicit weights, to have much welfare content. Rather oddly, the report's output series do not show which year's prices are (even in principle) being used. This could make a great deal of difference in a 1950 to 1968 comparison, because commodity prices in 1950 were severely affected by the recovery from the 1949 $r \Leftrightarrow$ cession and the start of the Korean War. 
contribution, especially in the larger economies - partly due to the influence of the 'Prebisch doctrine'. Imports have risen at a rate of only 3.2 per cent over the same period. In some countries, industrial complexes have been created which, with all their imperfections, do make further advances possible. Nevertheless, the chief social problems remain unsolved; indeed they are in some ways worse. From the very incomplete information available, income distribution seems at least as heavily concentrated in the hands of the rich as it was 20 years ago, and unemployment is greater, especially in its 'disguised' forms. The gap between town and country appears to have actually widened, whether we look at incomes, education and health services, or facilities such as electricity and water supplies (though from this particular generalisation we must exclude Argentina and Uruguay - and perhaps Chile). 1

As the report itself shows, the process of growth has been such that the benefits of industrialisation have not been spread at all adequately. Modern sectors have become in many ways more closely linked with foreign countries than with their rural hinterlands (something which could never have been said of the growth process of Britain or France); they have developed consumption patterns and production techniques which reflect those in far richer economies. With the notable exception of Cuba, ${ }^{2}$ foreign companies have played a big part in the import substitution process, and much of the benefit of the increased sales of manufactures has flowed abroad, not only in growing purchases of equipment and components, but also in rising profits and royalty payments. 3 Import substitution programmes have in fact of ten been too unselective to make much contribution to relieving the foreign exchange constraint, their primary objective. Production costs are too high for many of the new factories (strikingly in the automobile industry) to be able to export and indeed they can hardly have been established with this aim in view. 4

1 This does raise the question whether an economist from Argentina or Uruguay may not be tempted - like an Anglo-Saxon economist to base his model on his own national experience, though possibly with less damaging results.

2 There is actually no reference to Cuba (except a demographic one). This is odd in 1970, in a report on Latin America and of such generality; Cuba represents one of the two paradigms of 'change and development'。

3 The paper by Mr.Vaitsos in Vol. 3, No. 1 of the Bulletin is interesting in this connection.

4 Many of them would of course disappear if there was genuine economic integration. 


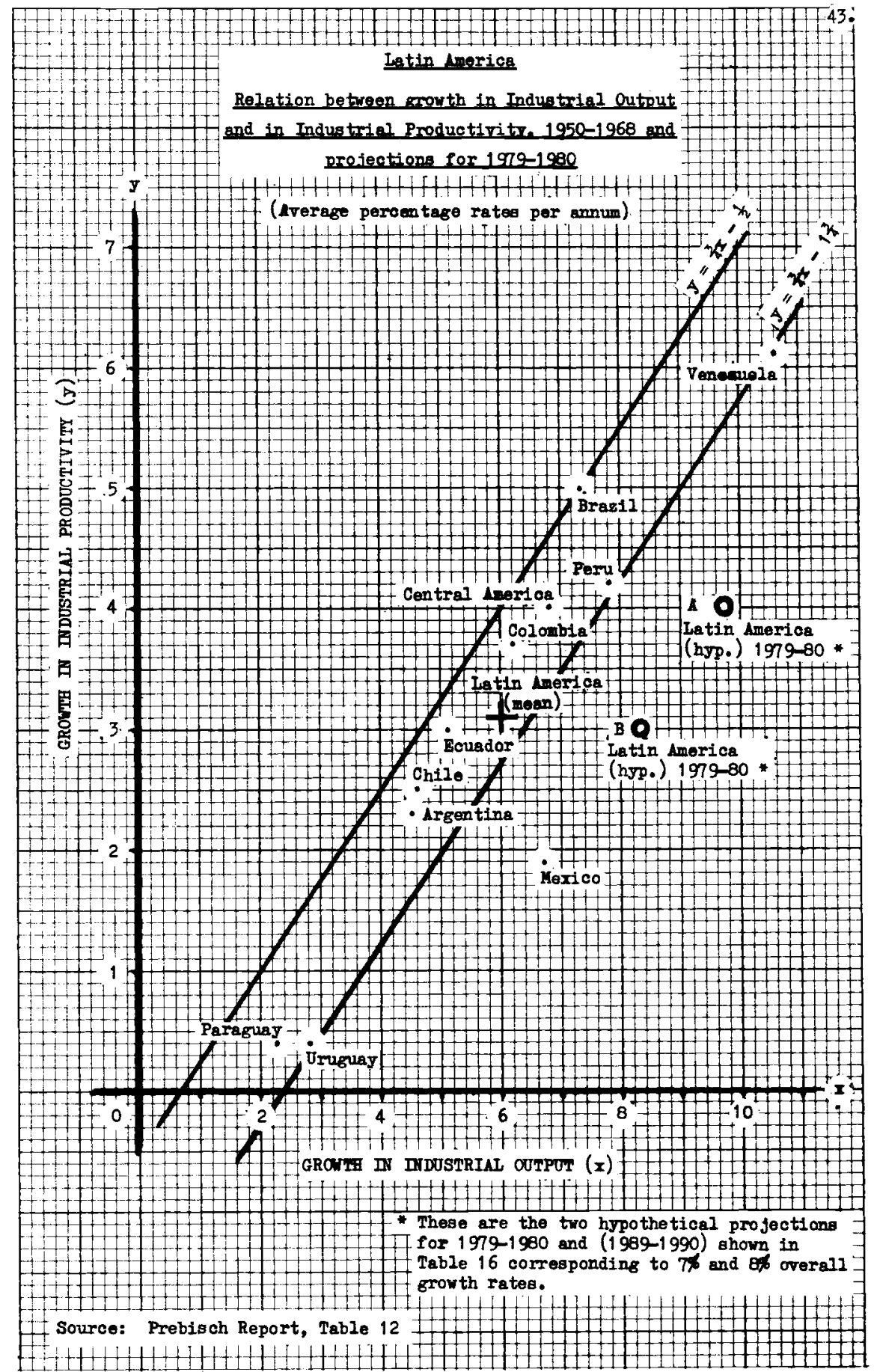


The other side of the coin, these new industrial plants have not done much to relieve unemployment either. The diagram, derived from table 12 in the report, 1 shows a relation between industrial growth $(X)$ and rises in labour productivity ( $Y$ ) over the 18 years 1950 to 1968 , which is astonishingly close if one allows for statistical weaknesses. The picture it reveals should make any growthmonger (Span. desarollista) pause. A regression band (drawn by eye) has been inserted to b ring out the relationship; it seems that about three-quarters of any increase in the growth of industrial output is accounted for by productivity rises (verifying Verdoorn's Law). Thus in Brazil, a $7 \%$ average growth in industrial output over this period was accompanied by a $5 \%$ rise in labour productivity and only $2 \%$ growth in employment; in Venezuela the corresponding figures were 11, 6 and 4. (Only Mexico shows a gain in employment more than half the rise in industrial production).

At the heart of the deepening structural problems of Latin America lies a process of industrialisation which seems to have become perverted, based as it is on the production of goods which do not require much labour. This points to income distribution and output techniques as places to look for clues.2 These are certainly not overlooked by Dr. Prebisch, but then the report covers a wide variety of subjects in one way or another. What gives away a writer's real concerms is what he attempts to handle quantitatively (even if only by the use of hypotheses), 3 and to integrate into his central model.

Questions are also raised about the educational systems of Latin America; these have apparently failed to induce more appropriate consumption patterns and attitudes to work or to provide the skilled manpower needed in various sectors. Bducation has always been neglected in Dr. Prebisch's frame of analysis; this seems especially conspicuous now, in view of the amount of research done in this field in the $1960^{\prime} \mathrm{s}$.

To question a diagnosis is naturally to question the prescription - broadly speaking, a bigger dose of $\mathrm{Dr}_{\mathrm{r}}$. Prebisch's remedy, growth. First there is a major question about the

Countries showing productivity declines have been excluded, and also Panama, for which the data in the table are internally inconsistent.

\section{2} mission to Colombia under IIO auspices - "Towards Full Employment" (II0 1970). See also Bulletin, Vol. 2 No. 4.

\section{3}

Income distribution is only analysed quantitatively in so far as it affects savings capacity - whereas a structural approach really requires quantification of the implications for the pattern of consumption. 
plausibility of the projections in view of past experience, 1 especially the realism of expecting industrialisation to make a much bigger impression on unemployment than it did in the past. Central to Dr。Prebisch's thesis is the assumption (table 16 of the Report) that by 1979-80 a growth of industrial output of $9.7 \%$ woild be accompanied by only a $4 \%$ rise in labour productivity, permitting a $5.5 \%$ increase in employment. This is shown on the diagram as Point $A$ (the alternative projection $B$ is based on slower growth). It would involve not merely an acceleration in inciastrial growth but also a big displacement (to the right of the regression band relating increases in industrial output and in productivity. Without such a shift, one would expect a growth of industrial output at nearly $10 \%$ to be associated with increased production of about $6 \%$, and of employment about $3 \frac{1}{2} \%$. What Dr. Prebisch is in fact assuming is a sharp rise in the degree of labour-intensity of output, throughout Latin America. Techniques may indeed be shifting - but in the opposite direction! A great deal of new industrial investment is bringing with it even more capital-intensive, indeed foreign-exchange-intensive, techniques; in fact many of the luxury products now being produced can hardly be manufactured in ways that provide much employment, especially for unskilled labour. In addition, the concentration of income may still be rising in many countries.

It is odd that these key projections are not derived from, indeed are quite inconsistent with, the historical data assembled in the report. The implications of the policy effort required by Dr. Prebisch's projections may thus be greater than he recognises. The change he predicates in the development process cal hardly be achieved without, inter alia, a more active screening of imported technology and a bigger redistribution of income than the report proposes - in fact without absolute declines in the real incomes of the rich.

Yet even what is proposed in the report is fairly drastic a tighter control on foreign investment and tax policies that woild only permit the top $5 \%$ of the population to increase consumption gradually in the next decade. Is this politically realistic? The new govermment in Chile appears ready for such measures - those of Bolivia and Peru, even Colombia, may also be Is there, however, any prospect at all of other governments adopting them, especially Brazil (which carries a heavy weight in regional averages)? Many regimes are in office precisely to prevent social change.

Sich governments can fall, but will the process of development be transformed and brought more under national control, even to the extent advocated in the report, without the co-operation of political forces which would seem so unpalatable to Washington and Wall street as to make still more unlikely the increases of

1 One wonders in passing how sensitive the regional import paojections are to different growth rates in different countries. 
46.

aid and foreign investment which are assumed? In fact an outflow of capital seems a more probable consequence of an opening to the Left. One need look no further than the recent experience of Chile。

There are other apparent inconsistencies. Would not the reforms proposed - of land tenure, taxation, tariff structure, etc. - almost certainly slow down growth, at least for a few years, while they were being digested, especially if carried out simultaneously? One set of such reforms has certainly had this effect in Cuba, but the same could well happen without a revolution, or even a change of government.

It is understandable that such questions are not usually posed in the publications of banks.1 (Indeed Dr. Herrera of IBD was rather courageous to publish a report which goes as $f a r$ as this one does). But my query - a sad one to have to ask about a document to which Dr. Prebisch has put his name - is whether the central analytical framework he employs, useful as it was in its time, does not now, in the $1970^{\prime} \mathrm{s}$, steer attention away from the real issues.

Surely growth rate targets are less important than social targets, whether for continents or countries. An $8 \%$ rate with certain patterns of growth, indeed with the existing distributions by sector and by income bracket, may well mean less development in the sense I use the word than (say) a $4 \%$ growth rate combined with firm measures to redistribute income. ${ }^{2}$ Indeed, from what we know of countries in the region with even $6 \%$ long-term growth rates in the 1950's and 1960's (such as Jamaica, Trinidad and Venezuela) it is questionable whether really fast growth can be achieved without such a heavy concentration on modern parts of the economy as to induce still greater dependence on foreign countries, still greater inequalities, and a continued, or even accelerated, increase in unemployment. (The rising wage rates in the leading sectors can, by emulation, inhibit the growth of other sectors, or actually destroy them). This in turn raises the question whether fast growth will not, even if it is feasible, eventually produce political stresses so severe as to bring itself to an end.

1 One wonders whether it will be very feasible henceforward, especially in Latin America, to continue to combine operational and professional careers as Dr. Prebisch has done so successfully and for so long.

2 It is true that in the case of Colombia, the combined implications of the targets we suggest for employment, and the guesses made about productivity imply a growth rate of $8 \%$. However this is not a target in itself - the emphasis is on the employment targets and the policies they imply, especially for incomes and technology needed to reach it. We raise in the report the question whether Colombia can achieve such far-reaching changes without reduction (para 844), but felt we should state the full economic requirements of a full employment policy. 
There is a curious lack of consistency between Dr. Prebisch's approaches in the two main fields of his life's work. In the field of international policy, he has - as shown by his reports as Secretary-General of UNCTAD - led the way by directing attention to the process of growth of the world economy, not its overall average rate; his work focusses on changes in the world income distribution, especially on the weaknesses of the mechanisms for spreading the growth of industrial areas to the 'periphery'. Yet for Latin America his central framework is aggregative, concentrating on national incomes, indeed total supra-national incomes covering nineteen nations, and attention is focussed primarily on the need $f(r$ fast overall growth, rather than on the processes of growth and problems of urban-rural integration. It is this model that needs change and development. 